\title{
COMPARISON OF CULTIVATED AND WILD RELATIVES OF SEVERAL FORAGE SPECIES IN MIXED RANGELAND BASED ON SOME NUTRITIONAL CHARACTERISTICS
}

\author{
Ibrahim AYDIN ${ }^{1}$, Betul PAK ${ }^{2}$, Nuh OCAK ${ }^{3 *}$ \\ ${ }^{1}$ Department of Field Crops, Faculty of Agriculture, University of Ondokuz Mayis, 55139, Samsun, Turkey \\ ${ }^{2}$ Department of Crop and Animal Production, University of Pamukkale, Tavas Vocational High School, 20500, Denizli, Turkey \\ ${ }^{3}$ Department of Animal Science, Faculty of Agriculture, University of Ondokuz Mayis, 55139, Samsun, Turkey
}

\begin{abstract}
Cultivated forage species may have higher nutrients contents (NC) and forage quality indicators (FQI) than their wild relatives. Nine forage samples collected five times from a mixed rangeland and an experimental field during two consecutive years was analysed for ash, crude protein (CP), ether extract (EE) and neutral detergent (NDF) and acid detergent (ADF) fibres. Then, their FQI such as digestible dry matter (DDM), dry matter intake (DMI), metabolizable energy (ME) and relative forage quality (RFQ) were calculated. Data were performed in a linear model with fixed effects (forage plant type [PT] and species [PS]) to NC and FQI, and subjected to hierarchical two-way clustering analysis. Cultivated and wilds relatives varied in CP (12.0-18.9\% and 8.8-23.3\%), ADF (20.9-33.1\% and 39.3-73.5\%) and NDF (37.2-61.6\% and 26.7-46.1\%) contents and ME (8.7-9.7 MJ kg-1 DM and 7.0-9.6 MJ kg-1 DM) and RFQ (98.8-186.7 and 74.6-161.7) values. There were interactions between PT and PS for all NC and FQI, except for CP and EE contents. In general, the $\mathrm{CP}, \mathrm{EE}, \mathrm{ADF}, \mathrm{ME}$ and $\mathrm{RFQ}$ of cultivars were higher, whereas NDF was lower than those of the wilds. The most notable differences (NDF, ADF and RFQ) between the PT represented the differences in nutritional traits based on the clustering analysis. The cultivated and wilds relatives are comprised of NC and FQI that respond differently under same circumstances.
\end{abstract}

Keywords: Forage quality, Grassland, Nutritive value, Nutrient content, Plant breeding

*Corresponding author: Department of Animal Science, Faculty of Agriculture, University of Ondokuz Mayis, 55139, Samsun, Turkey

E mail: nuhocak@omu.edu.tr (N. OCAK)

Ibrahim AYDIN (iD) https://orcid.org/0000-0001-7751-9896

Betul PAK (iD) https://orcid.org/0000-0002-5372-6222

Nuh OCAK (iD) https://orcid.org/0000-0001-7393-1373

Received: January 24, 2022

Accepted: February 15, 2022

Published: April 01, 2022

Cite as: Aydin I, Pak B, Ocak N. 2022. Comparison of cultivated and wild relatives of several forage species in mixed rangeland based on some nutritional characteristics. BSJ Agri, 5(2): 91-99.

\section{Introduction}

Rangelands and pastures subjected to intensive management are consisted of simple mixtures of only grass (Gramineae) varieties and cultivars or grass and legume (Leguminosae) species (Hayes et al., 2013) but are not included other botanical families (OBF) or nonleguminous forbs (Elgersma et al., 2014). However, natural and semi-natural rangelands are characterized by a rich botanical composition (Dudek et al., 2020) due to a more excellent range of species belonging to grasses, legumes and OBF (Aydin et al., 2019). Grasses increase yield and stability of rangelands, whereas the legume and OBF species improve both their productivity and nutritional value or quality (Capstaff and Miller, 2018). Therefore, understanding nutritional value, as well as productivity of the range forages, is useful for determining the capacity and ability of rangelands to meet the needs of animals (Asaadi and Yazdi, 2011; Aydin et al., 2020). The botanical composition of grasslands helps to explain nutritional value and production levels (Michaud et al., 2012; Aydın et al., 2020), whereas plant functional traits enable to link morphological, physiological and phenological plant properties to their functions (Schellberg and Pontes, 2012).

Forage crops utilized in both grazing and the cut-andcarry system meets the physical and physiological requirements of domesticated ruminants (Capstaff and Miller, 2018). Indeed, these crops not merely maintain these animals, but also sustain the delivery of meat, milk and other products (Hayes et al., 2013; Lee, 2018). However, one of the greatest challenges to the efficient production of ruminants is the shortage of forage resources available throughout critical periods of their production cycle (Uzun and Ocak, 2019). In such cases, to enhance ruminant productivity, the high-yield and nutritious native forages that cultivated (hereafter cultivars) are used in grazing or the cut-and-carry system (Aydin et al., 2019). Indeed, for re-vegetation and rehabilitation, the cultivars are introduced into the rangelands that composed of their wild relatives (Algan et al., 2019).

The yield and quality of herbage and persistence in forages, the primary production traits, are critical for 


\section{Black Sea Journal of Agriculture}

forage improvement in the various management systems and support feed conversion into unit quantities of an animal product as meat or milk (Hayes et al., 2013; Capstaff and Miller, 2018). The cultivation of forage plants has resulted in arguably the most desirable improvements such as dry matter (DM) yield and digestibility in forage species, such as Medicago, Trifolium, Lolium, and Festuca (Capstaff and Miller, 2018; Lee, 2018). Measuring the impacts of cultivars on high quality is very difficult since it needs laboratory analysis or animal feeding trials. Functional traits, such as digestible dry matter (DDM) and dry matter intake (DMI) that closely related to neutral detergent fibre (NDF) and acid detergent fibre (ADF) are easily measured predictor in quality of forage species (Bumb et al., 2016).

The information on whether cultivars may have higher nutrient content (NC) and forage quality indicators (FQI) than their wild relatives is scarce. Together with analysing distinct components of the wilds and the cultivars simultaneously may be useful to determine the impacts of species cultivation. Moreover, investigating the parallels and opposites between cultivars and wilds may help nutritional concepts and qualities of forages from biodiversity studies. Therefore, the objectives of this study were to determine similarities and differences between cultivars and wilds of several forage species that grown in field conditions and collected from rangeland, respectively and to provide to the farmers' useful recommendations on the best forage species to utilize.

\section{Materials and Methods}

\subsection{Study Area and Species Selection}

In this study, the third part of a research project (Aydın et al., 2018), the nine of forage species belong to cultivars and wild relatives (hereafter wilds) collected from an experimental field and the collected from the mountainous rangeland, respectively, $\left(40^{\circ} 50^{\prime}\right.$ to $41^{\circ} 51^{\prime} \mathrm{N}$ and $37^{\circ} 08^{\prime}$ to $34^{\circ} 25^{\prime} \mathrm{E}$ at nearly $1200 \mathrm{~m}$ above sea level) in Samsun province located in the middle Black Sea region of Turkey were used. The experimental field had a loam soil with sub-alkaline $\mathrm{pH}$, normal saline, low-lime, organic matter, $\mathrm{N}$ and $\mathrm{P}$, and high-K concentrations. The rangeland had a clay-loamy with sub-alkaline $\mathrm{pH}$, lowsaline, good organic matter, low- $\mathrm{N}$ and high-P and $\mathrm{K}$ contents (Tyler and Olsson, 2001). As was reported by Aydin et al. (2019), in the experimental area, winters are cool and damp, while summers are warm and damp for many years. The mean annual temperature and rainfall were $10.2^{\circ} \mathrm{C}$ (ranged from $3.1^{\circ} \mathrm{C}$ in winter to $16.7^{\circ} \mathrm{C}$ in summer) and $583.6 \mathrm{~mm}$ in the study period, respectively. Forage plant species in the study were perennial desirable such as Lotus corniculatus L. (L. corniculatus), Medicago sativa L. (M. sativa), Trifolium pratense L. (T. pratense), Trifolium repens L. (T. repens), Dactylis glomerata L. (D. glomerata), Festuca ovina L. (F. ovina), Lolium perenne L. (L. perenne) Cichorium intybus L. (C. intybus) and Sanguisorba minor Scop. (S. minor). The cultivars represent legume, grass and OBF species of unknown genetic type but which reared in private or state farms and research centres (Kazak Tarım, Ankara, Turkey). The wilds were the most dominant and promising species for region rangelands (Uzun and Ocak, 2019; Aydın et al., 2020).

\subsection{Collection and Laboratory Analyses of Forage Samples}

Samples of the forage plant types, defined as cultivars and wilds were collected five times at the active growth stages (from before-flowering stage to after-flowering stage) of dominant species in the rangelands in two consecutive years (2016 and 2017). The herbage samples taken at each collection period were dried at $60^{\circ} \mathrm{C}$ for 48 $\mathrm{h}$ in an air-forced oven and then, stored at $4{ }^{\circ} \mathrm{C}$ until the proximate analysis. For proximate analysis, all samples were ground with a 1-mm screen and then, analysed for dry matter (DM, ID number: 2001.12), CP (978.04), ether extract (EE, 920.39) and ash (930.05) as reported by AOAC (2005) procedures. The NDF and ADF contents of the samples were also determined using the ANKOM A200/220 (ANKOM Technology Corp., Fairport, NY, USA) fibre analyser filter bag technique (Van Soest et al., 1991). Then, their FQI such as DDM (equation 1), DMI (equation 2), metabolizable energy (ME, equation 3), relative feed value (RFV, equation 4) and relative forage quality (RFQ, equation 5) were calculated as described by Rohweder et al. (1978).

$\operatorname{DDM}(\%)=88.9-0.779 \times(\mathrm{ADF}, \%$ of $\mathrm{DM})$

DMI ( $\%$ of body weight, BW $)=120 /(\mathrm{NDF}, \%$ of DM $)$

$\mathrm{ME}\left(\mathrm{MJ} \mathrm{kg}^{-1} \mathrm{DM}\right)=0.17 \% \mathrm{DDM}-2.0$

(Belyea et al., 1993)

$\mathrm{RFV}=(\mathrm{DDM} \times \mathrm{DMI}) / 1.29$

$\mathrm{RFQ}=\left(\mathrm{DMI}_{\text {legume or grass, }} \%\right.$ of BW $) \times\left(\mathrm{TDN}_{\text {legume or grass, }} \%\right.$ of $\mathrm{DM}) / 1.23$

The $\mathrm{DMI}_{\text {legume or grass }}$ and total digestible nutrients (TDN) were calculated separately for legume and grass species as described by Undersander et al. (2010). Ten nutritional characteristics chosen for this study were among the most common agronomic metrics (Lee, 2018; Aydin et al., 2019).

\subsection{Statistical Analysis}

Data was performed by adjusting one linear model (equation 6) with fixed effects forage plant type (cultivars and wilds) and plant species (nine species) to the nutritional traits (NC and FQI). Analyses of variance were performed with GLM procedure of SPSS Statistics (Windows version of SPSS, release 21.0, SPSS Inc., Chicago, IL, USA)

$\mathrm{Y} i j k=\mu+\mathrm{PT} i+\mathrm{PS} j+\mathrm{PTPS} i j+e i j k$

Where: Yijk is the nutritional traits of $k$ species, of $i$ PT 


\section{Black Sea Journal of Agriculture}

(plant type) and $j$ PS (plant species); $\mu$ is the mean value; PT $i$ is an effect of plant type; PS $j$ is the effect of plant species; PTPSij is the interaction of the plant type and plant species factors, and eijk is the error value and then means were compared by Tukey's range test. The experimental unit for the cultivars and the wilds were the parcel and collection repetitions, respectively. The total number of samples was 65: two plant types $\times$ nine plant species $\times$ three or five (collection repetitions) $\times$ three (analytical replicates). The replication values of each trait for each species belonging to the wilds and cultivars were subjected to hierarchical two-way clustering analysis using the JMP statistical program (SAS Institute Inc.USA).
Thus, both plant type (as defined cultivated or wild type) and nutritional traits (as defined NC or FQI) were clustered according to similarity measures to simultaneously identify the associations between species and nutritional traits (Amiri and Shariff, 2012).

\section{Results}

Legumes contained higher CP, ash, DDM, DMI, ME, RFV and RFQ, and lower ADF and NDF than grasses (Table 1). Compared to the OBF species, legumes had higher CP and lower DMI, RFV and RFQ values, whereas grasses had lower DDM, RFV and RFQ, and higher CP, ash, ADF and NDF.

Table 1. The mean, standard error and 95\% confidence intervals of the studied variables of each forage family

\begin{tabular}{|c|c|c|c|c|c|c|c|c|c|c|}
\hline Variable $^{1}$ & $\mathrm{CP}$ & EE & Ash & ADF & NDF & DDM & DMI & $\mathrm{ME}$ & RFV & RFQ \\
\hline \multicolumn{11}{|l|}{ Legumes $(n=30)$} \\
\hline Mean & 18.7 & 2.4 & 9.5 & 39.6 & 36.2 & 64.3 & 2.79 & 8.9 & 140.5 & 141.8 \\
\hline Standard error & 0.63 & 0.13 & 0.24 & 1.71 & 1.17 & 0.61 & 0.065 & 0.10 & 4.49 & 5.25 \\
\hline \multicolumn{11}{|c|}{$95 \%$ confidence interval } \\
\hline Lower bound & 17.4 & 2.1 & 9.0 & 36.1 & 33.8 & 63.0 & 2.66 & 8.7 & 131.3 & 131.0 \\
\hline Upper bound & 19.9 & 2.6 & 10.0 & 43.1 & 38.6 & 65.5 & 2.93 & 9.1 & 149.7 & 152.5 \\
\hline \multicolumn{11}{|l|}{ Grasses $(n=22)$} \\
\hline Mean & 11.7 & 2.5 & 8.2 & 53.2 & 44.2 & 62.2 & 1.87 & 8.6 & 91.4 & 100.0 \\
\hline Standard error & 0.61 & 0.20 & 0.36 & 4.80 & 2.48 & 0.91 & 0.055 & 0.16 & 3.99 & 3.08 \\
\hline \multicolumn{11}{|c|}{$95 \%$ confidence interval } \\
\hline Lower bound & 10.5 & 2.1 & 7.4 & 43.2 & 39.1 & 60.3 & 1.76 & 8.3 & 83.1 & 93.6 \\
\hline Upper bound & 13.0 & 2.9 & 8.9 & 63.2 & 49.4 & 64.1 & 1.99 & 8.9 & 99.7 & 106.4 \\
\hline \multicolumn{11}{|c|}{ Other botanical families $(n=13)$} \\
\hline Mean & 11.1 & 2.5 & 10.1 & 39.7 & 37.9 & 64.1 & 2.84 & 8.9 & 148.4 & 147.6 \\
\hline Standard error & 0.71 & 0.22 & 0.54 & 4.14 & 2.63 & 2.08 & 0.179 & 0.35 & 13.34 & 13.76 \\
\hline \multicolumn{11}{|c|}{$95 \%$ confidence interval } \\
\hline Lower bound & 9.5 & 2.0 & 8.9 & 30.7 & 32.2 & 59.6 & 2.49 & 8.1 & 119.4 & 117.6 \\
\hline Upper bound & 12.6 & 2.9 & 11.3 & 48.7 & 43.6 & 68.6 & 3.27 & 9.7 & 177.9 & 177.5 \\
\hline
\end{tabular}

There were significant differences between the wilds and cultivars in terms of the NC (Table 1) and FQI (Table 2) variables. The content of $\mathrm{CP}$ was affected by the plant type and plant species factors, while EE content was only affected by plant type $(\mathrm{P}<0.001$, Table 2$)$. The wilds had lower CP (14.9\% vs $14.3 \%$ ) and EE (2.8\% vs $2.2 \%$ ) levels compared to the cultivars. The CP content of $M$. sativa was higher than those of other species $(\mathrm{P}<0.05)$, except for T. repens. The CP contents of $L$. corniculatus and $T$. pratense were higher $(\mathrm{P}<0.05)$ than those of the grasses (D. glomerata, F. ovina, and L. perenne) and the $\mathrm{OBF}$ species (C. intybus and $S$. minor). The grass and OBF species had similar values in CP content.

There were interactions between two factors for all NC (Table 2) and FQI (Table 3), except for CP and EE contents. Except for the cultivar T. repens, cultivar $C$. intybus had the highest ash content among the cultivars
( $\mathrm{P}<0.05)$, but did not differ from all wilds. The ADF content of the wild D. glomerata, F. ovina, and L. perenne and $C$. intybus had higher than those of the wild $L$. corniculatus, T. pratense and S. minor, and all cultivars (P $<0.05)$. The cultivar L. perenne had a lower ADL content compared to all wilds $(\mathrm{P}<0.05)$. In terms of the NDF content, the wild $C$. intybus had higher $(\mathrm{P}<0.05)$ value than the wild $S$. minor. The NDF contents of cultivar $F$. ovina and D. glomerata were higher than those of the other species, except for the cultivar T. pratense and the wild $C$. intybus $(\mathrm{P}<0.05)$.

The wild $S$. minor had a higher DDM value compared to the DMM values of the wild D. glomerata, $F$. ovina and $C$. intybus $(\mathrm{P}<0.05)$. These three wild types had lower DDM values compared to the cultivar T. repens, L. perenne and $S$. minor $(\mathrm{P}<0.05)$. Except for the cultivar T. repens, the DMI of the cultivar grasses was lower than those of the 


\section{Black Sea Journal of Agriculture}

cultivar legume and OBF species $(\mathrm{P}<0.05)$. The DMI of the wild D. glomerata and $F$. ovina were lower than all wild legumes and the wild $S$. minor $(\mathrm{P}<0.05)$. The cultivar legumes had a higher DMI level compared to the wild T. pratense, $C$. intybus and all wild grasses $(\mathrm{P}<0.05)$. The ME of the cultivar T. repens, L. perenne, S. minor and the wild $S$. minor were higher than those of the wild $D$. glomerata, F. ovina and C. intybus $(\mathrm{P}<0.05)$. The RFV of the cultivar T. repens was similar with cultivar L. perenne, wild M. sativa and wild T. repens, whereas the RFQ of the cultivar T. repens were higher than those of the wild $M$. sativa, T. pratense, T. repens and C. intybus as well as all grasses $(\mathrm{P}<0.05)$.

Table 2. Nutrients contents (\% of dry matter) of cultivated and wild types of some forage species belonging to grass, legume and other botanical families

\begin{tabular}{|c|c|c|c|c|c|c|}
\hline Plant type & Plant species & $\mathrm{CP}$ & $\mathrm{EE}$ & Ash & $\mathrm{ADF}$ & NDF \\
\hline \multicolumn{7}{|l|}{ Cultivars } \\
\hline & L. corniculatus & 17.4 & 2.7 & $8.2 \mathrm{~b}$ & $28.8 \mathrm{dfe}$ & $40.2 \mathrm{cde}$ \\
\hline & M. sativa & 18.9 & 2.1 & $8.7 \mathrm{~b}$ & $32.4 c-f$ & $43.4 \mathrm{bcd}$ \\
\hline & T. pratense & 15.7 & 2.4 & $8.3 b$ & $33.1 \mathrm{c}-\mathrm{f}$ & $46.6 \mathrm{abc}$ \\
\hline & T. repens & 18.0 & 2.5 & $9.6 a b$ & $26.6 \mathrm{ef}$ & $37.4 \mathrm{cde}$ \\
\hline & D. glomerata & 13.4 & 3.9 & $9.3 \mathrm{~b}$ & $31.0 \mathrm{dfe}$ & $57.9 \mathrm{ab}$ \\
\hline & F. ovina & 12.0 & 3.1 & $7.3 \mathrm{~b}$ & $30.6 \mathrm{dfe}$ & $61.6 a$ \\
\hline & L. perenne & 14.6 & 2.6 & $8.9 b$ & $20.9 f$ & $41.6 \mathrm{cde}$ \\
\hline & C. intybus & 12.3 & 2.7 & $10.3 \mathrm{a}$ & $30.0 \mathrm{dfe}$ & 40.1cde \\
\hline & S. minor & 11.9 & 3.0 & $9.3 \mathrm{~b}$ & $26.3 \mathrm{ef}$ & $42.4 \mathrm{~cd}$ \\
\hline \multicolumn{7}{|l|}{ Wilds } \\
\hline & L. corniculatus & 17.7 & 2.9 & $9.5 \mathrm{ab}$ & $41.4 \mathrm{bcd}$ & $29.9 \mathrm{de}$ \\
\hline & M. sativa & 23.3 & 2.5 & $9.7 \mathrm{ab}$ & $45.1 \mathrm{ab}$ & 32.1cde \\
\hline & T. pratense & 16.4 & 2.2 & $10.1 \mathrm{ab}$ & $49.5 b$ & $34.5 \mathrm{cde}$ \\
\hline & T. repens & 19.6 & 2.0 & $10.8 \mathrm{ab}$ & $45.5 \mathrm{ab}$ & $32.6 \mathrm{cde}$ \\
\hline & D. glomerata & 11.3 & 1.9 & $8.8 \mathrm{~b}$ & $71.1 \mathrm{a}$ & $38.6 \mathrm{cde}$ \\
\hline & F. ovina & 9.7 & 2.1 & $7.1 \mathrm{~b}$ & $73.5 \mathrm{a}$ & $39.0 \mathrm{cde}$ \\
\hline & L. perenne & 10.7 & 1.9 & $7.8 b$ & $68.2 \mathrm{a}$ & 35.1cde \\
\hline & C. intybus & 8.8 & 2.3 & $9.9 \mathrm{ab}$ & $63.3 a$ & $46.1 \mathrm{abc}$ \\
\hline & S. minor & 11.2 & 2.0 & $8.6 b$ & 39.3b-e & $26 . \mathrm{e}$ \\
\hline \multicolumn{7}{|l|}{ Plant type } \\
\hline Cultivars & & $14.9 \mathrm{a}$ & $2.8 \mathrm{a}$ & 9.2 & 45.7 & 28.9 \\
\hline Wilds & & $14.3 \mathrm{~b}$ & $2.2 \mathrm{~b}$ & 9.1 & 25.0 & 55.2 \\
\hline \multicolumn{7}{|l|}{ Plant species } \\
\hline L. corniculatus & & $17.6 \mathrm{~b}$ & 2.8 & 8.9 & 35.0 & 35.1 \\
\hline M. sativa & & $21.6 \mathrm{a}$ & 2.3 & 9.3 & 36.2 & 40.4 \\
\hline T. pratense & & $16.2 \mathrm{~b}$ & 2.3 & 9.4 & 39.0 & 43.3 \\
\hline T. repens & & $19.0 \mathrm{a}$ & 2.2 & 10.3 & 34.3 & 38.4 \\
\hline D. glomerata & & $12.1 \mathrm{c}$ & 2.6 & 9.0 & 45.9 & 56.0 \\
\hline F. ovina & & $10.7 \mathrm{c}$ & 2.5 & 7.2 & 48.7 & 55.1 \\
\hline L. perenne & & $12.4 \mathrm{c}$ & 2.2 & 8.3 & 37.9 & 48.0 \\
\hline C. intybus & & $10.6 \mathrm{c}$ & 2.5 & 11.5 & 43.2 & 46.7 \\
\hline S. minor & & $11.5 c$ & 2.4 & 8.9 & 33.4 & 33.8 \\
\hline SEM & & 0.59 & 0.01 & 0.22 & 2.11 & 1.20 \\
\hline \multicolumn{7}{|l|}{ Main effect of } \\
\hline Plant type & & $<0.001$ & $<0.001$ & $<0.001$ & $<0.001$ & $<0.001$ \\
\hline Plant type & & $<0.001$ & 0.888 & $<0.001$ & $<0.001$ & $<0.001$ \\
\hline Plant type $\times$ Plant type & & 0.111 & 0.062 & 0.040 & $<0.001$ & 0.001 \\
\hline
\end{tabular}

$\overline{a, c, d}$ Means of the same column followed by different letters differ significantly $(\mathrm{P}<0.05)$.

$\mathrm{CP}=$ crude protein, $\mathrm{EE}=$ ether extract, $\mathrm{ADF}=$ acid detergent fibre, $\mathrm{NDF}=$ neutral detergent fibre, $\mathrm{SEM}=$ standard error of mean. 
Table 3. Forage quality indicators of cultivated and wild-types of some forage species belonging to grass, legumes and other botanical families

\begin{tabular}{|c|c|c|c|c|c|c|}
\hline Plant type & Plant species & DDM $^{1}$ & DMI & ME & RFV & RFQ \\
\hline \multicolumn{7}{|l|}{ Cultivars } \\
\hline & L. corniculatus & $66.5 \mathrm{ab}$ & $3.11 \mathrm{ab}$ & $9.3 \mathrm{ab}$ & $162.3 \mathrm{ab}$ & $175.5 \mathrm{abc}$ \\
\hline & M. sativa & 63.7ab & $2.83 \mathrm{abc}$ & $8.8 \mathrm{ab}$ & $140.4 \mathrm{abc}$ & $151.2 \mathrm{a}-\mathrm{e}$ \\
\hline & T. pratense & 63.1ab & 2.66a-e & $8.7 \mathrm{ab}$ & 131.7a-e & 141.3a-f \\
\hline & T. repens & $68.2 \mathrm{a}$ & $3.31 \mathrm{a}$ & $9.6 \mathrm{a}$ & $176.3 \mathrm{a}$ & $186.7 \mathrm{a}$ \\
\hline & D. glomerata & $64.8 \mathrm{ab}$ & $2.09 \mathrm{~d}-\mathrm{g}$ & $9.0 \mathrm{ab}$ & $105.4 c-f$ & 106.6e-h \\
\hline & F. ovina & $64.4 \mathrm{ab}$ & $1.96 \mathrm{efg}$ & $9.0 \mathrm{ab}$ & $98.9 c-f$ & $98.5 e-h$ \\
\hline & L. perenne & $69.0 \mathrm{a}$ & $2.34 \mathrm{c}-\mathrm{g}$ & $9.7 \mathrm{a}$ & $125.2 \mathrm{a}-\mathrm{f}$ & $125.5 c-h$ \\
\hline & C. intybus & $65.5 \mathrm{ab}$ & $3.19 \mathrm{ab}$ & $9.1 \mathrm{ab}$ & $165.7 \mathrm{ab}$ & 166.9a-d \\
\hline & S. minor & $68.4 \mathrm{a}$ & $3.20 \mathrm{ab}$ & $9.6 \mathrm{a}$ & $175.3 \mathrm{ab}$ & $182.4 \mathrm{ab}$ \\
\hline \multicolumn{7}{|l|}{ Wilds } \\
\hline & L. corniculatus & 65.7ab & $2.93 \mathrm{abc}$ & $9.2 \mathrm{ab}$ & 149.1abc & 143.4a-f \\
\hline & M. sativa & 63.9ab & $2.70 a-d$ & 8.9ab & $134.7 a-d$ & $129.4 b-g$ \\
\hline & T. pratense & 62.1abc & $2.48 b-f$ & $8.5 \mathrm{abc}$ & $120.6 b-f$ & $115.8 \mathrm{~d}-\mathrm{h}$ \\
\hline & T. repens & $63.5 \mathrm{ab}$ & 2.66a-e & 8.8ab & 131.8a-e & $126.5 \mathrm{c}-\mathrm{h}$ \\
\hline & D. glomerata & $58.8 \mathrm{bc}$ & $1.70 \mathrm{~g}$ & $8.0 \mathrm{bc}$ & 77.9ef & $84.7 \mathrm{gh}$ \\
\hline & F. ovina & $58.5 b c$ & $1.63 \mathrm{~g}$ & $7.9 \mathrm{bc}$ & $74.1 \mathrm{f}$ & 93.4fgh \\
\hline & L. perenne & $61.5 \mathrm{abc}$ & $1.76 \mathrm{fg}$ & $8.5 \mathrm{abc}$ & 83.9def & $102.9 \mathrm{e}-\mathrm{h}$ \\
\hline & C. intybus & $53.0 \mathrm{c}$ & $1.90 \mathrm{fg}$ & $7.0 \mathrm{c}$ & 78.1ef & $74.6 \mathrm{~h}$ \\
\hline & S. minor & $68.1 \mathrm{a}$ & $3.13 a b$ & $9.6 \mathrm{a}$ & $168.0 \mathrm{ab}$ & 161.7a-d \\
\hline \multicolumn{7}{|l|}{ Plant type } \\
\hline Cultivars & & 66.0 & 2.74 & 9.2 & 142.4 & 148.3 \\
\hline Wilds & & 61.7 & 2.32 & 8.5 & 113.1 & 114.7 \\
\hline \multicolumn{7}{|l|}{ Plant species } \\
\hline L. corniculatus & & 66.1 & 3.02 & 9.2 & 155.7 & 159.4 \\
\hline M. sativa & & 63.8 & 2.75 & 8.9 & 136.9 & 137.6 \\
\hline T. pratense & & 62.5 & 2.55 & 8.6 & 124.8 & 125.4 \\
\hline T. repens & & 65.2 & 2.91 & 9.1 & 148.4 & 149.1 \\
\hline D. glomerata & & 61.1 & 1.85 & 8.4 & 88.3 & 92.9 \\
\hline F. ovina & & 61.0 & 1.77 & 8.4 & 84.7 & 95.5 \\
\hline L. perenne & & 64.8 & 2.01 & 9.0 & 101.6 & 112.6 \\
\hline C. intybus & & 59.3 & 2.55 & 8.1 & 121.9 & 120.8 \\
\hline S. minor & & 68.2 & 3.16 & 9.6 & 171.1 & 170.6 \\
\hline SEM & & 0.59 & 0.075 & 0.10 & 4.70 & 4.54 \\
\hline \multicolumn{7}{|l|}{ Main effect of } \\
\hline Plant type & & $<0.001$ & $<0.001$ & $<0.001$ & $<0.001$ & $<0.001$ \\
\hline Plant species & & $<0.001$ & $<0.001$ & $<0.001$ & $<0.001$ & $<0.001$ \\
\hline Plant type $\times \mathrm{Pl}$ & species & 0.013 & 0.004 & 0.013 & 0.014 & 0.009 \\
\hline
\end{tabular}

a,c,d Means of the same column followed by different letters differ significantly $(\mathrm{P}<0.05)$. DDM= digestible dry matter, DMI= dry matter intake, $\mathrm{ME}=$ Metabolizable energy, $\mathrm{RFV}=$ relative feed value, $\mathrm{RFQ}=$ Relative forage quality.

${ }^{1}$ Unit of DDM, DMI, and ME is \% of dry matter, \% of body weight, and MJ $/ \mathrm{kg} \mathrm{DM}$, respectively.

Both cultivars and wilds separated into two main clusters (named as I and II) according to the similarity of the nutritional traits (Figure 1). In terms of the families and the number of subset and species, there was no similarity among the species within the clusters (I and II) of both cultivars and the wilds. The Cluster I of the cultivars had 


\section{Black Sea Journal of Agriculture}

two species (F. ovina and D. glomerata), whereas that of the wilds had two sub-groups that had one (C. intybus) and three (L. perenne, F. ovina, and D. glomerata) species, respectively. Cluster II of both cultivars and wilds showed two subsets ( $\mathrm{II}_{1}$ and $\left.\mathrm{II}_{2}\right)$. The $\mathrm{II}_{1}$ and $\mathrm{II}_{2}$ subsets of the cultivars included two (T. pratense and M. sativa) and five (L. perenne, C. intybus, S. minor, L. corniculatus and T. repens) species, respectively. Despite that, the $\mathrm{II}_{1}$ and $\mathrm{II}_{2}$ subsets of the wilds included one ( $S$. minor) and four ( $T$. pratense, L. corniculatus, T. repens and M. sativa) species, respectively. Based on the dendrogram, the most similar species pairs were T. repens - L. corniculatus, S. minor - C. intybus, M. sativa - T. pratense and D. glomerata - F. ovina in the cultivars, whereas M. sativa - T. repens and $D$. glomerata - F. ovina in the wilds. The plant type clustered into two sets that included similar NC and FQI. However, the most similar pairs were RFV - RFQ and ADF - NDF in the cultivars, while RFV - RFQ and ADF - DDM in the wilds.
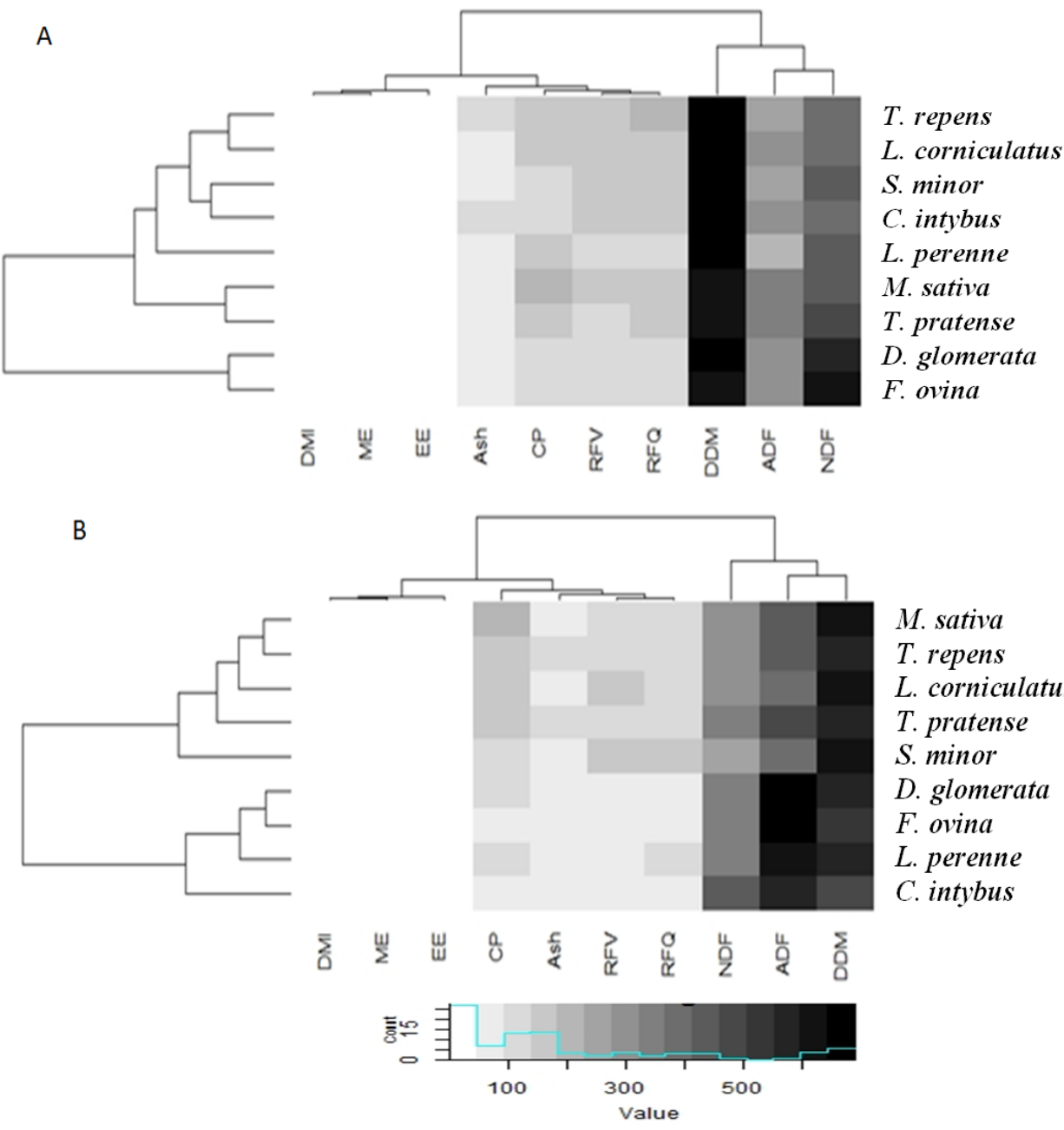

M. sativa

T. repens

L. corniculatus

T. pratense

S. minor

D. glomerata

F. ovina

L. perenne

C. intybus

Figure 1. Dendrograms that derived from a two-way clustering analysis of the nine cultivated forage species (A) and their wild relatives (B) together with their nutritional traits. The horizontal and vertical dendrogram is the clusters of plant species and nutritional traits, respectively, according to similarities in the studied parameters. The intensity of colour histogram indicates the lowest (light white) and the highest (dark black) strength of similarity. $\mathrm{CP}=\mathrm{crude}$ protein, $\mathrm{EE}=$ ether extract, $\mathrm{ADF}=$ acid detergent fibre, $\mathrm{NDF}=$ neutral detergent fibre, $\mathrm{DDM}=$ digestible dry matter, $\mathrm{DMI}=$ dry matter intake, $\mathrm{ME}=$ metabolizable energy, $\mathrm{RFV}=$ relative feed value, $\mathrm{RFQ}=$ relative forage quality.

\section{Discussion}

The results of the present study indicated that the cultivars and the wilds comprised of components that respond differently to ecological processes under the same circumstances. Indeed, the cultivars resulted in a remarkable higher nutritive value relative to the wilds. These results confirmed that the quality, one of the primary production traits (Hayes et al., 2013) for forage species, is improved by cultivation of forage species (Lee,
2018). All nutritional traits of both cultivars and wilds were within the range reported in the literature (Asaadi and Yazdi, 2011; Bidgoli et al., 2013; Lee, 2018; Aydin et al., 2019). In agreement with Asaadi and Yazdi (2011), therefore, adequate nutrients were available in rangelands that included the studied wilds. The most notable was that the ADF content, the RFV, and RFQ values of cultivars were a mean of $30 \%$ higher and the NDF content was $48 \%$ lower than those of the wilds. 
These findings might be related to the fact that the legume and OBF cultivars generally had lower ADF and NDF, and higher ash concentrations than their wilds and all grasses (Elgersma et al., 2014; Aydin et al., 2019). These changes in nutritional traits that represented the quality of the forages are very critical in terms of digestible nutrients and energy provision to the ruminants (Hayes et al., 2013). Available study results (Dudek et al., 2020) indicate that differences in the nutrient content of the forage species depend on the difference between years in terms of season (Fan et al., 2020), and, in particular, the amount of precipitation (Gulwa et al., 2017). Unfortunately, we did not estimate the year $\times$ species or type interaction in the present study because the samples collected in each year were mixed at the end or were not analysed separately.

Because the cultivars such as M. sativa, L. corniculatus, $D$. glomerata, S. minor, and CI are highly valuable and palatable species for ruminants (Aydın et al., 2020), these cultivars are introduced within the degraded rangeland for re-vegetation and restoration purposes (Schröder and Prasse, 2013; Uzun et al., 2015; Așcl, 2016; Algan et al., 2019). Based on our results, the use of mixtures of the legume and OBF cultivars (L. corniculatus, M. sativa, $T$. pratense, $S$. minor and $C$. intybus) for that aim may cause the combined beneficial impacts for the rangelands (Kemp et al., 2010; Hutton et al., 2011) due to the higher $\mathrm{CP}$ and lower ADF and NDF contents in these cultivars than companion grasses (Elgersma et al., 2014). Grazing such rangelands may help to boost the productivity of animals and to diminish costs (Algan et al., 2018). However, it should remember that the potential of rangeland improvement by the cultivars depends upon whether they are good competitors to the present vegetation in stressful environmental factors (Schröder and Prasse, 2013).

The productivity of the OBF species and their use for livestock is much lower than the grass and legume species (Elgersma et al., 2014). As reported previously (Elgersma et al., 2014; Aydin et al., 2019), the wild $S$. minor and $C$. intybus generally showed lower FQI values due to $\mathrm{CP}, \mathrm{ADF}$, and NDF contents. The results of the present study indicated that the OBF species cultivated relatively new compared to the grass and legume forage caused significant improvements in the FQI of the OBF cultivars. The differences between the cultivars and the wilds may be due to leaf form, structure and leaf to stem ratio (Onoda et al., 2017; Lee, 2018; Aydin et al., 2019). The increased NC and FQI in the cultivars may, also, be due to the impacts of fertilizer applied in the field conditions (Onoda et al., 2017; Lee, 2018; Algan et al., 2019). Indeed, the $M E$ and $R F Q$ values of the OBF cultivars were higher than the grass cultivars, but not the legumes. The results of two-way clustering analysis confirmed the significant differences among nutritional traits of the cultivars and the wilds. These findings supported the idea that the $C$. intybus and S. minor provide a suitable balance between $\mathrm{CP}$ and energy, as well as minerals and thus, these species may cause highanimal productivities in harsh environments (Asaadi and Yazdi, 2011). Indeed, plant type containing high-CP and ash as well as low-ADF and NDF representing highdigestibility are more nutritious (Arzani et al., 2010; Lee, 2018).

Due to the interaction effect between plant type and plant species factors, there was substantial variation between the cultivars and the wilds. This interaction suggested that the cultivars may differ in their rates of response to cultivation pressures and also, the responses of species in terms of nutritional traits may not always be equally strong, as described previously (Capstaff and Miller, 2018; Pfeiffer et al., 2018). Indeed, variation in CP and EE values within and between the studied species was less compared with ADF and NDF values. In the present study, grass species had a lower feeding value due to insufficient CP content and unsatisfactory fibre digest for ruminants compared to the legumes and the OFB species (Amiri and Shariff, 2012; Algan et al., 2019; Aydin et al., 2019). The fact that grass species had a lower ME and RFQ compared to the species from legume and the other families could be associated with their cell wall and contents (Aydin et al., 2019). Therefore, both types of grass species may limit animal productivity. However, the NC and FQI results of the studied wilds indicated that these species were sufficient in guaranteeing the roughages required by grazing ruminants (Amiri and Shariff, 2012; Elgersma et al., 2014).

The results of the hierarchical two-way clustering analysis showed that the wilds and the cultivars were comprised of nutritional traits that respond differently under the same circumstances. The colour histogram of the dendrogram showed that low-NC and FQI were rare in the cultivars or common in the wilds. These clustering groups agree with the results of previous studies (Amiri and Shariff, 2012; Aydin et al., 2019) related to the rangeland forages. The clusters of families in both the cultivars and wilds were probably related to the NC and FQI of the species belonging to each family (Arzani et al., 2010; Amiri and Shariff, 2012; Aydin et al., 2019). Although the significant variations within and between the forage plant species, the results of clustering analysis confirmed that ADF and NDF contents of forages were the best quality indicator (Ruckle et al., 2017; Lee, 2018; Aydin et al., 2019).

\section{Conclusion}

The results of the present study indicate that, under normal circumstances, the cultivars resulted in a remarkable higher nutritive value relative to the wilds. Also, the results divulge that legume (L. corniculatus, $M$. sativa, T. pratense and T. repens) and probably the OBF species (C. intybus and $S$. minor) are highly acceptable to enhance the productivity of ruminants compared to grasses (D. glomerata, F. ovina and L. perenne). The information reported herein may help to improve the 


\section{Black Sea Journal of Agriculture}

animal diet based on the wilds and to farmers for increasing productivity of the small ruminants.

\section{Author Contributions}

IA; supervision project administration and resources. IA and NO; funding acquisition, conceptualization, methodology and writing-original draft preparation. BP and NO; investigation, data curation and formal analysis. NO; writing-review and editing, All authors have read and agreed to the published version of the manuscript.

\section{Conflict of Interest}

The author declared that there is no conflict of interest.

\section{Acknowledgments}

The authors thank the Scientific and Technological Research Council, TUBITAK (Project no: 2140 228) for financial support. We want to thank Dr D. Algan and Dr H.S. Abacı for their valuable contribution to laboratory work and statistical analysis, respectively.

\section{References}

Algan D, Aydın İ, Ocak N. 2018. Economic analysis of fertilization based on nutritional value of rangeland: A new opinion. Anadolu J Agr Sci, 33: 246-253.

Algan D, Ocak N, Aydin I. 2019. Productive potential and quality of overgrazed rangelands subjected to overseeding and fertilization. Fresenius Environ Bullet, 28: 5916-5925.

Aşcı ÖÖ. 2016. Importance of Clover (Trifolium sp.) Genus for Black Sea Region. Tr J Agric-Food Sci Technol, 4: 1-4.

Amiri F. Shariff ARBM. 2012. Comparison of nutritive values of grasses and legume species using forage quality index. Songklanakarin J Sci Technol, 34: 577-586.

Arzani H, Ahmadi Z, Azarnivand H, Bihamta MR. 2010. Forage quality of three life forms of rangeland species in semi-arid and semi humid regions in different phenological stages. Desert, 15: 71-74.

Asaadi AM, Yazdi AK. 2011. Phonological stage effects on forage quality of four forbs species. J Food Agric Environ, 9: 380384.

AOAC 2005. Association of Official Analytical Chemists. Official Methods of Analysis. 18th edn. Arlington, VA, USA.

Aydın İ, Ocak N, Pak B, Süzer RP. 2018. Experiments on development of quality index in forage crops based on relative forage quality (RFQ). The Scientific and Technological Research Council of Turkey, Agriculture, Forestry and Veterinary Research Group, AFVRG-Project No2140228, Report of Final Results.

Aydın İ, Pak B, Algan D, Ocak N. 2020. Floristic patterns and qualities of forage species from mountainous rangeland in the Middle Black Sea Region of Turkey. Tr J Agric Food Sci Technol, 8: 733-740.

Aydin, I, Algan D, Pak B, Ocak N. 2019. Similarity analysis with respect to some quality indicators and quality categories based on relative forage quality ranges of desirable rangeland forages. Fresenius Environ Bullet, 28: 5926-5936.

Beecher M, Hennessy D, Boland TM, McEvoy M, O'Donovan M. Lewis E. 2015. The variation in morphology of perennial ryegrass cultivars throughout the grazing season and effects on organic matter digestibility. Grass Forage Sci, 70: 19-29.

Belyea RL, Steevens B. Garner G. Whittier JC, Sewell H. 1993. Using NDF and ADF to balance diets. Agric Publication, G.
3161.

Bidgoli DR, Ranjbarforoei A. Akhzari D. 2013. Estimation of nutritive values of some range species as indicators for rangelands management. J Rang Sci, 2: 669-676.

Bumb I, Garnier E, Bastianelli D. Richarte J, Bonnal L, Kazakou E. 2016. Influence of management regime and harvest date on the forage quality of rangelands plants: the importance of dry matter content. AoB Plant, 8: plw045.

Capstaff NM, and Miller AJ. 2018. Improving the yield and nutritional quality of forage crops. Front Plant Sci, 9: 535.

Dudek T, Wolański P, Rogut K. 2020. The content of macro-and micro minerals in the sward of different types of semi-natural meadows of temperate climate in SE Poland. Agronomy, 10: 273.

Elgersma A, Søegaard K, Jensen SK. 2014. Herbage dry-matter production and forage quality of three legumes and four nonleguminous forbs grown in single-species stands. Grass Forage Sci, 69: 705-716.

Fan Q, Wang Z, Chang S, Peng Z, Wanapat M, Hou F. 2020. Relationship of mineral elements in sheep grazing in the highland agro-ecosystem. Asian Australas J Anim Sci, 2020, 33: 44-52.

Gulwa U, Mgujulwa, N, Beyene ST. 2017. Effect of grass-legume intercropping on dry matter yield and nutritive value of pastures in the Eastern Cape Province, South Africa. Univers J Agric Res, 5: 355-362.

Hayes BJ, Cogan NO, Pembleton LW, Goddard ME, Wang J, Spangenberg GC, Forster JW. 2013. Prospects for genomic selection in forage plant species. Plant Breed, 132: 133-143.

Hutton PG, Kenyon PR, Bedi MK, Kemp PD, Stafford KJ, West DM, Morris ST. 2011. A herb and legume sward mix increased ewe milk production and ewe and lamb live weight gain to weaning compared to a ryegrass dominant sward. Anim Feed Sci Technol, 164: 1-7.

Kemp PD, Kenyon PR, Morris ST. 2010. The use of legume and herb forage species to create high performance pastures for sheep and cattle grazing systems. R Bras Zootec, 39: 169-174.

Lee MA. 2018. A global comparison of the nutritive values of forage plants grown in contrasting environments. J Plant Res, 131: 641-654.

Michaud A, Andueza D, Picard F, Plantureux S, Baumont R. 2012. Seasonal dynamics of biomass production and herbage quality of three grasslands with contrasting functional compositions. Grass Forage Sci 67: 64-76.

Onoda Y, Wright IJ, Evans JR, Hikosaka K, Kitajima K, Niinemets Ü, Poorter H, Tosens T, Westoby M. 2017. Physiological and structural tradeoffs underlying the leaf economics spectrum. New Phytolog, 214: 1447-1463.

Pfeiffer VW, Ford BM, Housset J, McCombs A, Blanco-Pastor JL, Gouin N, Manel S, Bertin A. 2018). Partitioning genetic and species diversity refines our understanding of species-genetic diversity relationships. Ecol Evol, 8: 12351-12364.

Rohweder DA, Barnes RF, Jorgensen N. 1978. Proposed hay grading standards based on laboratory analyses for evaluating quality. J Anim Sci, 47: 747-759.

Ruckle M, Meier M, Frey L, Eicke S, Kölliker R, Zeeman SC, Studer B. 2017. Diurnal leaf starch content: an orphan trait in forage legumes. Agron, 7:16.

Schellberg J. Pontes LDS. 2012. Plant functional traits and nutrient gradients on grassland. Grass Forage Sci, 67: 305319.

Schröder R. Prasse R. 2013. Do Cultivated varieties of native plants have the ability to outperform their wild relatives? PLoS ONE 8: e71066.

Tyler G. Olsson T. 2001. Plant uptake of major and minor 


\section{Black Sea Journal of Agriculture}

mineral elements as influenced by soil acidity and liming. Plant and Soil, 230: 307-321.

Undersander D, Moore JE, Schneider N. 2010. Relative Forage Quality. Madison, WI, USA: University of Wisconsin-Madison. Focus Forage. 12:1-3.

Uzun F, Dönmez HB, Ocak N. 2015. Genetic potential of wild birdsfoot trefoil (Lotus corniculatus L.) seeds collected from different geographical locations regarding to nutrient composition and nutritive value. Agroforest Syst, 89: 963-
972.

Uzun F, Ocak N. 2019. Some vegetation characteristics of rangelands subjected to different grazing pressures with single- or multi-species of animals for a long time (A case of Zonguldak province, Turkey). Anadolu J Agr Sci, 34: 360-370.

Van Soest PJ, Robertson JB, Lewis BA. 1991. Methods for dietary fiber, neutral detergent fiber, and non-starch polysaccharides in relation to animal nutrition. J Dairy Sci, 74: 3583-3597. 